\title{
The Image of Immigration in Fiction Broadcast on Prime-time Television in Spain ${ }^{1}$
}

\author{
Juan José Igartua² \\ Isabel M. Barrios ${ }^{3}$ \\ Félix Ortega ${ }^{4}$ \\ Francisco J. Frutos ${ }^{5}$
}

Recibido: 2013-11-13

Envío a pares: 2013-12-01
Aprobado por pares: 2014-01-10

Aceptado: 2014-01-27

DOI: 10.5294/pacla.2014.17.3.2

Para citar este artículo / To reference this article / Para citar este artigo

Igartua, J., Barrios, I. M., Ortega, F., \& Frutos, F. J. Septiembre de 2014. The Image of Immigration in Fiction Broadcast on Prime-time Television in Spain. Palabra Clave 17 (3), 589-618. DOI: 10.5294/pacla.2014.17.3.2

\section{Abstract}

The article describes the results of a content analysis of the image of immigrants portrayed in prime- time television fiction in Spain, based on the cultivation theory and research on ethnic minorities in the media. The data indicates immigrant characters clearly are underrepresented and tend to be depicted in a negative way that reinforces stereotypes about immigrants (e.g., performing criminal activities). The results are discussed in relation to the role television fiction could play in reducing prejudice through mediated intergroup contact (Park, 2012).

1 This study was carried out thanks to financing provided by the Programa de Apoyo a Proyectos de Investigación de la Consejería de Educación de la Junta de Castilla y León (Research Project Support Program of the Castile \& Leon Regional Ministry of Education ) (Reference No. SA006A10-1).

2 Universidad de Salamanca, España.jigartua@usal.es

Universidad de Salamanca, España. imbv@usal.es

Universidad de Salamanca, España. fortega@usal.es

Universidad de Salamanca, España. frutos@usal.es 


\section{Keywords}

Mass communication, communication impact, intercultural communication (Source: UNESCO Thesaurus).

\section{La imagen de la inmigración en la ficción transmitida en horario estelar en la televisión española}

\section{Resumen}

El artículo describe los resultados de una investigación de análisis de contenido sobre la imagen de los inmigrantes en los programas de ficción emitidos en el horario de prime time de televisión en España, basado en la teoría de cultivo y la investigación sobre las minorías étnicas en los medios de comunicación. Los datos permiten concluir que existe una infra-representación de los personajes inmigrantes, y también se observa que éstos tienden a ser representadosde manera negativa reforzando los estereotipos sobre los inmigrantes. Se discuten los resultados en relación con el papel que podría desempeñar la ficción televisiva en la reducción de los prejuicios a través del contacto mediado intergrupal (Park, 2012).

\section{Palabras clave}

Comunicación masiva, el impacto de la comunicación, comunicación intercultural (Fuente: Tesauro de la Unesco). 


\section{A imagem da imigração na ficção transmitida no horário nobre na televisão espanhola}

\section{Resumo}

Este artigo descreve os resultados de uma pesquisa de análise de conteúdo sobre a imagem dos imigrantes nos programas de ficção emitidos no horário nobre na Espanha, baseado na teoria do cultivo e da pesquisa sobre as minorias étnicas nos meios de comunicação. Os dados permitem concluir que existe uma infrarrepresentação dos personagens imigrantes e também se observa que estes tendem a ser representados de maneira negativa, o que reforça os estereótipos sobre os imigrantes. Discutem-se os resultados sobre o papel que poderia desempenhar a ficção televisiva na redução do preconceito por meio do contato mediado intergrupal (Park, 2012).

\section{Palavras-chave}

Comunicação massiva, o impacto da comunicação, comunicação intercultural (Fonte: Tesauro da Unesco). 


\section{Introduction}

The role of the media is becoming more and more decisive in people's lives. The wide range of devices through which one can be connected to the media means the consumption of media messages gradually takes up more time in our daily lives. Besides the instrumental uses of media and communication technologies (especially the Internet), the media have colonized a great part of leisure time. Television is still dominant: $88.6 \%$ of the population in Spain watches television every day, as opposed to the $43.4 \%$ who are Internet users (AIMC, 2012). In addition, apart from constituting a powerful industry, television is a system focused on storytelling (Shanahan \& Morgan, 1999). In this context of a high degree of television consumption and regarding the preeminence of ritualistic usage (or one linked to the search for entertainment), it is possible to wonder how the fiction shown on Spanish television represents immigration. Immigration is one of the most important and recent social phenomena to emerge in the country and has become even more controversial in the present scenario of an economic crisis. To wit, Spain's demography has changed during the last two decades owing to the arrival and settlement of foreigners. Although the present context of economic crisis meant a slight drop in the growth of the immigrant population during the last two years, current demographic data show1 $1.7 \%$ of Spain's population was foreign as of January $1,2013(5,520,133$ persons; Spain's National Bureau of Statistics [INE], 2013), compared to $12.2 \%(5,730,667$ personas) reported for January 1, 2011 (INE, 2011).

However, the opening of borders to immigration is not always accompanied by a welcoming host population (Cea D'Ancona, 2004). Data from surveys carried out in Spain show an ambivalent stance towards immigration on the part of the indigenous population. Accordingly, when those surveyed were asked: "How would you say Spaniards, in general, treat immigrants?" the response most selected (from the six suggested) to describe this treatment was invariably the expression: "As if they don't trust them". This choice of response was selected on most survey occasions (from 1996 to 2010) by four out of every ten responders (Cea D'Ancona \& Valles, 2011). Although there are many different factors that can explain this attitude of rejection or ambivalence towards the immigrant population, media 
coverage of the phenomenon has been shown to be a relevant one, since it tends to highlight the alarm felt about the arrival of immigrants by oftentimes using expressions such as "avalanche" or "invasion" or linking the increase in immigration to criminality (Igartua, Muñiz, Otero \& de la Fuente, 2007). However, although there are numerous studies analyzing the image of immigration in the news and the possible socio-cognitive effects that could explain attitudes of rejection towards immigrants (Igartua \& Cheng, 2009; Igartua, Moral \& Fernández, 2011; Schemer, 2012), less research has been done on a systematic analysis of the image of immigrants in television fiction contents most likely to be watched by a great many people; i.e. those broadcast during prime time. This is especially relevant if we consider the fact that, for many people, their only interaction with persons coming from other countries and cultures is the product of vicarious or parasocial contact (Schiappa, Gregg \& Hewes, 2005). In their study Evolución del racismo y la xenofobia en España (Evolution of Racism and Xenophobia in Spain), Cea D'Ancona and Valles (2011) found only $42 \%$ of the participants had friendships with immigrants.

The following article examines the image of immigrants portrayed in prime-time television fiction through the main results of a content analysis research study carried out in 2011 ; specifically, an analysis of 1,788 characters in 77 programs (TV series and films) broadcast on the six national channels that capture most of the audience in Spain (TVE1, La 2, Antena 3, Cuatro, Tele 5, and La Sexta). This paper also includes theoretical reflection on the importance of fictional characters in shaping attitudes and beliefs as a possible explanation for the spreading of stereotypes and prejudice towards immigrants, as well as to account for the possible beneficial uses of mediated intergroup contact (Harwood, 2010; Müller, 2009; Park, 2012).

\section{Television Fiction and Social Perception of Reality}

Empirical research confirms that television consumption exerts a meaningful effect on the perception of our social world (Shanahan \& Morgan, 1999). The first attempt at systematizing empirical research on the representation of social reality in television fiction, and at analyzing its impact on audiences, was the Cultural Indicators Project led by George Gerbner, 
which would give way to the cultivation theory. The latter focuses on determining the social consequences of messages broadcast through television, and on studying the effects of conventional television programming designed to "entertain" viewers (especially fiction shows with a narrative structure, such as series and films). From this theoretical perspective, television is considered to be a cultural instrument that socializes conduct and social roles, and shapes basic assumptions about social reality (Morgan \& Shanahan, 2010; Morgan, Shanahan \& Signorelli, 2009).

Gerbner and his collaborators have based their work of the last few decades on three kinds of data: institutional analysis of the media, analysis of the message system, and analysis of cultivation (Signorelli \& Morgan, 1996). First, institutional analysis of the media examines how television messages are produced and distributed. Through message system analysis, Gerbner and his team register and analyze weekly samples of drama shows on prime-time television and children's programming on weekends. This is done through content analysis. Finally, cultivation analysis empirically determines the influence of television contents on viewers' perception of the world. Research developed in light of the cultivation theory has been based mainly on representative surveys of the population, analyzing the relation between television consumption and social beliefs on various issues, so as to determine whether television has an effect on influencing viewers' conceptions (Morgan et al., 2009).

Studies developed to verify the cultivation hypothesis have shown television consumption is associated with a high perception of risk and danger, and with maintaining an exaggerated sense of mistrust, vulnerability and insecurity (Gerbner, Gross, Morgan, Signorelli \& Shanahan, 2002; Morgan et al., 2009). Similarly, it brings about the belief that we live in a just world (Appel, 2008), and reduces satisfaction with life through the promotion of materialism (Shrum, Lee, Burroughs \& Rindfleisch, 2011). Furthermore, television consumption influences the perception of gender roles, professions, environmental matters, gender violence, disability, attitudes towards partner relationships, and social perception of ethnic minorities (Morgan, 2009; Morgan \& Shanahan, 2010; Morgan et al,. 2009; Shanahan \& Mor- 
gan, 1999). Even though the estimated effect is low $(r=.10)$, it persists under the control of multiple variables (Shanahan \& Morgan, 1999). Hence, there has been a repeated emphasis on the need to analyze or monitor the degree of diversity existing in television programming, given the impact its contents could have on audiences and public opinion (Koeman, Peeters \& D’Haenes, 2007).

\section{Mediated Intergroup Contact and Prejudice}

Gordon Allport (1954) defined prejudice as "an antipathy based upon a faulty and inflexible generalization" (p. 9). It is a negative or rejecting attitude towards an individual because he/she belongs to a specific group (Molero, 2007). It has been possible to determine that one of the most efficient strategies to reduce prejudice is to allow for interaction or direct contact between persons of the in- and out-groups (Pettigrew \& Tropp, 2006). Moreover, there are two mechanisms that have been observed as being able to reduce prejudice: intergroup contact lowers intergroup anxiety and increases empathy towards the out-group members (Pettigrew \&Tropp, 2008). It also has been perceived that contact can have a positive effect even if it is indirect, vicarious or merely symbolic; this is where the role of audiovisual fiction can be determinant (Fujioka, 1999; Harwood, 2010; Müller, 2009; Schiappa et al., 2005). Park (2012) defines mediated intergroup contact as the parasocial interaction produced between an in-group spectator (e.g. national or native) and a fictional character belonging to an out-group (e.g. immigrant or foreigner). Such intergroup contact also takes place when an in-group viewer identifies with a fictional character who belongs to the viewer's own group and becomes involved in friendly or favorable interaction with an out-group character. According to the extended contact hypothesis, "knowledge that an in-group member has a close relationship with an out-group member can lead to a more positive intergroup attitude" (Wright, Aron, McLaughlin-Volpe \& Ropp, 1997, p. 74). In this sense, the parasocial contact hypothesis maintains that exposure through the mass media (e.g. television or films) to examples of positive and successful inter-cultural relationships between characters from the in- and out-groups consitutes an opportunity for parasocial contact that strengthens attitudes of acceptance towards members of the out-group. Conversely, the imagined inter- 
group contact hypothesis (Crisp \& Turner,2009) propounds that even the mere fact of imagining a positive encounter with a person belonging to an out-group (in this case, an immigrant) leads to less prejudice. In fact, there is empirical evidence to support the hypothesis of extended and imagined contact when applied to the field of media communications (Igartua, 2010; Müller, 2009; Ortiz \& Harwood, 2007; Paluck 2009). Considering all of the above, it is possible to conclude that indirect or media contact with immigrant or foreign characters can lead to a reduction in prejudice towards a foreign or immigrant group, provided the representation of immigrant characters and the interactions they establish with national-native characters in fictional programs are positive and non-stereotypical.

\section{Ethnic Minorities and Immigrants in Television Fiction}

To date, research has been done on the role of framing immigration in the news media as one of the main factors behind the increase in xenophobia (Brader, Valentino \& Suhay, 2008; Igartua, Moral \& Fernández, 2011; Schemer, 2012). However, the invisibility of immigration or a distorted (stereotypical) view portrayed in television fiction also can constitute an important element that may explain the formation, reinforcement and internalization of a prejudicial attitude towards immigrants. In this sense, a relevant line of research is the one related to an analysis of the representation of ethnic and cultural minority characters in television fiction (African-Americans, Latinos, Asian-Americans and Native Americans in the United States, or immigrants in the Spanish and European contexts) (Greenberg, Mastro \& Brand, 2002; Mastro \& Greenberg, 2000).

Research analyzing the content of fictional television programs concluded the presence of ethnic minority characters in the sample is low, as they usually are under-represented (Mastro, 2009a, 2009b). In addition, it also has been observed that characters belonging to ethnic minorities usually occupy less relevant roles in the narrative structure of such programs (Greenberg \& Collette, 1997; Mastro\& Greenberg, 2000). Furthermore, when there are ethnic minority characters, they usually are accompanied by a distorted or stereotypical view. Thus, it has been observed that: (a) violence, crime and offenses are strongly associated with ethnic mino- 
rities (Entman \& Rojec, 2000); (b) Latinos appearing in US television fiction tend to focus their conversations on topics such as crime and violence more frequently than characters of Caucasian origin (Mastro \& Greenberg, $2000)$; (c) there is more frequent use of excessive or extreme force by police agents in television fiction towards youths belonging to ethnic minorities, which might suggest these characters are victimized more than those of Caucasian origin (Mastro \& Robinson, 2000); and (d) Latinos are represented negatively in television fiction as lazy, performing low-skilled occupations, not intelligent, and demonstrating difficulties to expressing themselves or communicating effectively (Harwood \& Anderson, 2002; Mastro \& Behm-Morawitz, 2005).

In Spain, empirical research on the depiction of immigration in television fiction is practically nonexistent (Ruiz-Collantes, Ferrés, Obradors, Pujadas \& Pérez, 2006; Galán, 2006; Lacalle, 2008; Igartua, Barrios \& Ortega 2012). Galán (2006) performed her research through a content analysis of the image of immigration in fiction, but tackled only two television series. Lacalle's work (2008) showed, in the assessed contents, that: (a) immigrant characters are predominantly portrayed in an irregular situation and with lower-skill qualifications; (b) there is high presence of immigrants acting as criminals or being victims of violent action or crime; and (c) the presence of qualified immigrants or those incarnating a central role in the narrative is infrequent in all the series analyzed. As for Ruiz-Collantes et al. (2006), they found immigrant characters tended to be portrayed as non-leading and were represented mainly in a negative light, by being associated with problems and victimization. They also were shown to be ineffective in achieving their self-proposed goals, so they tended to simulate, manipulate or cheat. The study by Igartua, Barrios \& Ortega (2012), based on the cultivation theory, analyzed a wide representative sample of fictional characters ( 1,345 in 88 programs). Their first main result indicated $7.8 \%$ of the characters in domestic shows were immigrants-foreigners, as opposed to $92.2 \%$ who were national-native. Since Spain's foreign population in 2010 was about $12.2 \%$ of the total, it could be said the immigrant-foreigner collective was under-represented in fiction broadcast on television. Furthermore, it was noted that immigrant- 
foreign characters, as opposed to nationals-natives, were portrayed with a lower level of education, less stable jobs, or performing criminal activities, displaying more violent behavior and being on the receiving end of more acts of violence (meaning they performed their actions in more conflictive environments). Moreover, they were defined as less efficient from a cognitive point of view (less hard-working, intelligent or tolerant). Nonetheless, the definition of "character" was excessively restrictive in that study: for a character to be part of the analysis, it had to appear in the program "more than once" and had to have several lines of dialogue with other characters (the work of Koeman et al., 2007 was adopted as a reference). This criterion may have "excluded from the analysis" many characters who perhaps came into view only once. Considering this and taking into account the aforementioned research indicating that characters belonging to ethnic or cultural minorities usually have less important roles in these narratives, the presence of immigrant-foreign characters may have been underestimated. Accordingly, a less restrictive definition was used in the study presented herein. All characters who met one condition were considered: for a character to be considered in the analysis, he/she must have appeared visually throughout the show and must have at least one line of dialogue with other characters. Considering existing research on the image or portrayal of immigrants and ethnic minorities in television fiction, as well as studies analyzing the way immigration is framed in the news, the following hypotheses were established.

H1. - There will be under-representation of immigrant characters in primetime television fiction.

H2. - There will be a greater frequency of antagonist or villain characters, secondary leading, and secondary non-leading characters (and fewer main character roles) among immigrant or foreign characters compared to national or native ones.

H3. - Immigrant or foreign characters will have a lower level of education, a lower socio-economic status and will perform lower-skilled occupations compared to national-native characters. 
H4. - There will be significant differences between immigrant-foreign characters and national-native ones regarding displays of violent behavior, victimization, health problems, conversation topics, and personality traits.

\section{Method}

\section{Sample of Contents}

Two full weeks of prime-time programming on the six national channels in Spain (TVE1, La 2, Antena 3, Cuatro, Tele 5 and La Sexta) were recorded. According to the Estudio General de Medios (General Mass Media Survey), their combined share of television consumption in Spain comes to 64.2\% (AIMC, 2012). Two composite week samples were randomly selected in the year 2011, and 77 programs (30 films and 47 series) were identified. Of these, $62.4 \%$ had been produced in the United States of America, $31.2 \%$ in Spain, 3.9\% were of other European origin, and 2.6\% came from a different country. Character selection began once the fictional programs were identified. For a character to be part of the analysis, he/she had to appear visually throughout the show and had to have one line of dialogue with another (other) character(s); that is, the character had to be a talking individual (Koeman et al., 2007). Thus, 1,788 characters were identified.

\section{Codebook}

The basis for the analysis of fictional shows and their characters was a codebook created from previous studies (Harwood \& Anderson, 2002; Igartua et al., 2012; Koeman et al., 2007; Mastro \& Behm-Morawitz, 2005; Mastro \& Greenberg, 2000; Potter \& Warren, 1998).

Basic identification data. The following aspects were evaluated: date the program aired, day of the week it aired, and the television channel it was broadcast on.

Program information. This section included the following variables: a) production origin ( $0=$ unidentified, $1=$ domestic origin, Spain, $2=$ United States, 3 = another European country, $4=$ Latin America, 5 = another cou- 
ntry); b) program type ( 1 = feature-length film, 2 = series, serial, sitcom, miniseries, or procedural series); c) program duration (in minutes, excluding advertising); and, $d$ ) place where the main action occurs ( $1=$ Spain, $2=$ another European country, 3 = the United States, $4=$ Latin America, 5 $=$ another country).

Narrative aspects of the character. The narrative role of the character in the program was evaluated using the following code: $1=$ protagonist (the one who performs the most important actions in the story; the dramatic structure revolves around this character and his or her actions); 2 = antagonist or villain (the most important character in opposition to the protagonist); 3 = secondary protagonists (those closely related to the protagonist or main character; their participation in the story is important and their actions move in the same direction as those of the protagonist); $4=$ secondary non-protagonists (their participation in the story is not very important; their presence is not essential and is not closely related to either the protagonist or the antagonist).

Socio-demographic aspects of the character. The following variables were assessed with regard to each character: a $)$ gender $(1=$ male, $2=$ female $), b)$ age group ( $1=$ child, between 0 and 12 years of age; $2=$ adolescent, between ages 13 and 17; 3 = young adult, between ages 18 and 30; 4 = adult, between ages 31 and 64; $5=$ elderly, over age 65); c) educational level (0 = cannot be identified; 1 = illiterate, cannot read or write; 2 = no formal education; 3 = primary school, 4 = middle and upper secondary school, vocational school; $5=$ university); $d$ ) socio-economic level ( $0=$ cannot be identified; 1 = low, working class or lower class, do not earn enough to satisfy their basic needs; 2 = middle class, characters who work for a living, meet their needs and can afford a few luxuries; 3 = upper class, characters who need not work to maintain their standard of living or have a job that allows them to enjoy many luxuries not available to the majority); e) occupation was coded according to a list that was established by the Centro de Investigaciones Sociológicas (CIS, Spain's Centre for Sociological Research) for analyzing occupations (17 different occupations are included, plus the category 0 = cannot be identified; see Table 5). 
A relevant feature of this study is the evaluation of the character's nationality. ${ }^{1}$ As it oftentimes would be difficult to discern the birthplace of the character, this criterion was weighed based on a group of attributes or characteristics that had to be evaluated jointly or separately:(a) the birthplace of the character (provided it was explicitly mentioned in the program); (b) the birthplace of one of the character's parents, since the possibility of being a "second-generation immigrant" was included when at least one of the parents had been born abroad; (c) biological characteristics or phenotypic traits (e.g. shape of the eyes, skin color , type of hairstyle); (d) cultural characteristics (e.g. way of dressing, name of the character, accent); and (e) motivation to be in another country (working, studying, on holiday). The evaluation of nationality invariably took into account the country where most of the action in the narrative takes place. Considering the previously mentioned variables, the following code was used to classify the nationality of the character: 0 = not clearly identifiable; $1=$ national of the country where most of the action takes place (native, if the character resides in his/ her country of birth); 2 = foreigner, the person is coming from one country but staying in another temporarily (e.g. due to studies, vacation or business); and 3 = immigrant, the character has abandoned his/her country or origin and arrives in another to reside there with a specific work project. A character also could be categorized as a (second-generation) "immigrant" when at least one of the parents was not born in the country where most of the narrative takes place, and had established residence in another for the purpose of work.

Violent behavior by the character. Using a dichotomous scale ( $0=$ no, 1 = yes), we coded the presence of different types of behavior or modes of violence based on Potter and Warren's classification (1998): a) performing "major physical attacks," b) performing "minor physical attacks," c) performing acts that cause "property damage," d) performing acts of "intimidation" and, e) making "hostile comments". An index of violent behavior was created from the sum of these five variables.

Violent behavior towards the character. Using a dichotomous scale ( $0=$ no, $1=$ yes $)$ and Potter and Warren's classification (1998), we coded 
whether the character being analyzed suffered from or was a victim of the following types or modes of violence: a) major physical attacks, b) minor physical attacks, c) acts causing property damage, d) acts of intimidation and, e) hostile comments. A character victimization index was created from the sum of these variables.

Problematic health behavior shown by the character. We coded ( $1=$ yes, $0=$ no) whether or not the character: a) consumed alcoholic beverages, $b$ ) smoked tobacco, c) took prescription drugs, d) consumed illegal drugs and e) exhibited a problematic eating disorder. An index of health problems was devised from the sum of these five variables.

Conversation topics uttered by the character. Using a dichotomous scale $(0=$ no, $1=$ yes $)$, we coded whether or not the character conversed with other characters at some point during the program about the following topics: love, violence, friendship, sex, money, social differences, work, the environment, health, education, family, politics, sports, racism and immigration. A conversational richness index was created for each character by adding the fifteen aforementioned variables.

Character's personality traits. The personality traits of the character (friendly, open or extrovert, kind or good-hearted, disloyal, unfair, aggressive, intelligent, hard-working, grateful, conflictive, racist and intolerant) were pondered with a three-point scale $(1=$ it is not a trait of the character, $2=$ it partially or moderately defines the personality of the character; $3=$ it perfectly defines the personality of the character). Moreover, an additional code was used (value 0 ) for those cases in which the personality of the character could not be coded because the character had a minor presence in the show, making it difficult to objectively evaluate his/her psychological profile. Two personality indices were created for each character: a positive personality traits index (friendly, open or extrovert, kind or good-hearted, intelligent, hard-working, grateful: $\alpha=.85$ ), and a negative personality traits index (disloyal, unfair, aggressive, conflictive, racist and intolerant: $\alpha=.80$ ). 


\section{Coding}

The coding of these 1,788 characters was undertaken by eight (8) analysts with training in audiovisual communication and research methods. After the codification process was complete, a new analysis was conducted on 284 randomly selected characters to assess the reliability of the coding process. Intercoder reliability was computed using Krippendorff's alpha coefficient (Hayes \& Krippendorff, 2007). The "nationality" variable had a very acceptable value (Krippendorff's $\alpha=.80$ ), as did the variable concerning the "country where the main part of the narrative takes place" (Krippendorff's $\alpha=.81){ }^{2}$ The "personality" variables and those involving conversational topics showed lower intercoder reliability values; hence, these last results should be treated cautiously. When the conversational topics and personality traits variables were excluded, the results for intercoder reliability were satisfactory (Krippendorff's $\alpha=.66$ ).

\section{Results}

\section{Hypothesis 1}

According to the Instituto Nacional de Estadística (National Bureau of Statistics) (INE, 2011), the population of foreigners registered as living in Spain on January 1, 2011 was 5,730,667; that is, $12.2 \%$ of the total $(47,150,819$ residents). The results of this study show $89.8 \%$ of the characters on television were nationals or natives, $4.2 \%$ were foreigners and $5.1 \%$ were immigrants, while the nationality of $0.9 \%$ could not be determined. Since the INE does not differentiate between foreigners and immigrants, a new variable was created in which the characters without a nationality were eliminated, and a sole unified group of "immigrant-foreigners" was generated (9.3\%). Based on these figures, it was possible to infer there is an under-representation of immigrants-foreigners in the sample of the characters analyzed $\left(\chi^{2}\right.$ $[1, N=1772]=11.13, p<.001)$. Furthermore, statistically significant differences emerged when the origin of the program was taken into account $\left(\chi^{2}[2, N=1772]=146.43, p<.001\right)$. The percentage of immigrant-foreign characters in the programs produced in Spain was substantially reduced (up to $4.4 \%$ ), while their presence was greater in shows produced in other countries (36.7\%). 


\section{Table 1}

\section{Relationship Between Nationality of the Character and Origin of the Program in Which the Character Appears (\% column)}

\begin{tabular}{|c|c|c|c|c|}
\hline \multirow{2}{*}{ Nationality of the Character } & \multirow{2}{*}{ Total \% } & \multicolumn{3}{|c|}{ Origin of the Program } \\
\cline { 3 - 5 } & & Domestic Origin (Spain) & USA & Other Country \\
\hline - National-Native & 90.6 & $95.6+$ & $91.7+$ & $63.3-$ \\
\hline - Immigrant-Foreigner & 9.4 & $4.4-$ & $8.3-$ & $36.7+$ \\
\hline $\mathrm{N}$ & 1772 & 563 & 1062 & 147 \\
\hline
\end{tabular}

- Statistically significant lower value (adjusted standardized residuals analysis)

+ Statistically significant higher value (adjusted standardized residuals analysis).

\section{Hypothesis 2}

Hypothesis 2 assumes a relationship between the narrative role of the character and his/her nationality. Again, there were statistically significant differences between national-native and foreign-immigrant characters in the narrative roles of the programs $\left(\chi^{2}[3, N=1772]=15.20, p<.001\right)$. The nationals-natives and immigrants-foreigners were distributed similarly in protagonist ( $11.9 \%$ versus $15 \%)$ and secondary leading roles $(17.6 \%$ versus $22.8 \%)$. However, the role of antagonist/villain was more frequent among immigrants-foreigners (12\%) than among nationals-natives (6\%).Thus, Hypothesis 2 was supported by the data.

\section{Table 2}

\section{Relationship Between the Nationality of the Character and the Narrative Role (\% Column)}

\begin{tabular}{|l|c|c|c|}
\hline \multirow{2}{*}{ Type of Character } & \multirow{2}{*}{ Total \% } & \multicolumn{2}{|c|}{ Nationality of the Character } \\
\cline { 3 - 4 } & & National-Native & Immigrant-Foreigner \\
\hline • Protagonist & 12.2 & 11.9 & 15.0 \\
\hline - Antagonist or villain & 6.6 & $6.0-$ & $12.0+$ \\
\hline - Secondary leading & 18.1 & 17.6 & 22.8 \\
\hline - Secondary non-leading & 63.1 & $64.4+$ & $50.3-$ \\
\hline \multicolumn{1}{|c|}{$\mathrm{N}$} & 1772 & 1148 & 190 \\
\hline
\end{tabular}

- Statistically significant lower value (adjusted standardized residuals analysis)

+ Statistically significant higher value (adjusted standardized residuals analysis). 


\section{Hypothesis 3}

Hypothesis 3 assumes the existence of significant differences between national-native and immigrant-foreign characters in the variables dealing with level of education, socio-economic status and occupation. As for the level of education, there were statistically significant differences $\left(\chi^{2}[5, N=1772]\right.$ $=28.99, p<.001)$; specifically, level of education could not be determined for a high percentage of the immigrant-foreign characters $(38.9 \%)$. This did not occur with national-native characters (30.7\%). Moreover, the percentage of illiteracy was higher among the immigrant-foreign characters (4.2\%) than among nationals-natives $(0.6 \%)$.

\section{Table 3}

\section{Relationship Between the Nationality of the Character and Level of Education (\% Column)}

\begin{tabular}{|l|c|c|c|}
\hline \multirow{2}{*}{ Level of Education } & \multirow{2}{*}{ Total \% } & \multicolumn{2}{|c|}{ Nationality of the Character } \\
\cline { 3 - 4 } • Unable to be identified & 31.4 & National-Native & Immigrant-Foreigner \\
\hline • Illiterate & 1.0 & $30.7-$ & $38.9+$ \\
\hline • No studies & 3.5 & $0.6-$ & $4.2+$ \\
\hline • Primary & 9.3 & 3.4 & 4.8 \\
\hline • Secondary & 19.8 & 9.6 & 6.0 \\
\hline • University & 26.3 & 24.7 & 19.8 \\
\hline & 1772 & 31.1 & 26.3 \\
\hline
\end{tabular}

- Statistically significant lower value (adjusted standardized residuals analysis)

+ Statistically significant higher value (adjusted standardized residuals analysis).

A statistically significant association also was noted between the nationality of the character and his/her socio-economic status $\left(\chi^{2}[3, N=1772]\right.$ $=10.63, p<.014)$. Immigrants-foreigners appeared more frequently in a lower socio-economic status (19.2\%) than did nationals-natives (10.8\%). 
Table 4

\section{Relationship Between the Nationality of the Character and Socio-Economic Status ( $\%$ Column)}

\begin{tabular}{|c|c|c|c|}
\hline \multirow{2}{*}{ Socio-economic Status } & \multirow{2}{*}{ Total \% } & \multicolumn{2}{|c|}{ Nationality of the Character } \\
\hline & & National-Native & Immigrant-Foreigner \\
\hline - Could not be identified & 1.2 & 1.3 & 0.6 \\
\hline - Low & 11.6 & $10.8-$ & $19.2+$ \\
\hline - Medium & 73.0 & 73.6 & 67.1 \\
\hline • High & 14.2 & 14.3 & 13.2 \\
\hline $\mathrm{N}$ & 1772 & 1605 & 167 \\
\hline
\end{tabular}

- Statistically significant lower value (adjusted standardized residuals analysis)

+ Statistically significant higher value (adjusted standardized residuals analysis).

Finally, a statistically significant association was observed with respect to occupation $\left(\chi^{2}[17, N=1772]=92.24, p<.001\right)$.Immigrant-foreign characters had a higher probability of carrying out criminal activities ( $21 \%$ as opposed to $5.7 \%$ of the nationals-natives), performing lower-skilled jobs (10.2\% versus $4.7 \%)$, and working at another profession not specified in the list $(7.8 \%$ versus $4 \%)$. Furthermore, the national-native characters were more likely to be students ( $9.4 \%$ versus $3 \%$ of the immigrants-foreigners). Based on these results, Hypothesis 3 was confirmed by the data (see Table 5). 


\section{Table 5}

\section{Relationship Between the Nationality of the Character and Occupation or Main Activity (\% Column)}

\begin{tabular}{|c|c|c|c|}
\hline \multirow{2}{*}{ Occupation or Main Activity } & \multirow{2}{*}{ Total \% } & \multicolumn{2}{|c|}{ Nationality of the Character } \\
\hline & & National-Native & Immigrant-Foreign \\
\hline - Could not be identified & 16.5 & $17.4+$ & $8.4-$ \\
\hline - Does not have a stable occupation & 0.7 & 0.6 & 1.8 \\
\hline - Director or high-level professional & 5.6 & 5.9 & 3.6 \\
\hline - Technician or medium-level professional & 13.1 & 13.0 & 13.8 \\
\hline - Small businessperson & 2.6 & 2.6 & 2.4 \\
\hline - Office and services clerk & 2.6 & 2.7 & 1.2 \\
\hline - Skilled worker & 3.6 & 3.6 & 3.6 \\
\hline - Non-skilled worker & 5.2 & $4.7-$ & $10.2+$ \\
\hline $\begin{array}{l}\text { - Farmer, stockbreeder/rancher, fisherman } \\
\text { (primary sector) }\end{array}$ & 0.7 & 0.7 & 0.6 \\
\hline - Member of a religious order & 1.6 & 1.8 & 0.0 \\
\hline - Police and/or military person & 20.7 & 20.9 & 19.2 \\
\hline - Retired and/or pensioner & 1.3 & 1.4 & 0.6 \\
\hline - Unemployed & 1.3 & 1.4 & 0.0 \\
\hline - Student & 8.8 & $9.4+$ & $3.0-$ \\
\hline - Unpaid domestic & 1.6 & 1.7 & 0.0 \\
\hline - Sports, artist or show-business person & 2.4 & 2.3 & 3.0 \\
\hline - Other occupation (not in the list) & 4.3 & $4.0-$ & $7.8+$ \\
\hline - Character's job involves criminal activities & 7.2 & $5.7-$ & $21.0+$ \\
\hline $\mathrm{N}$ & 1772 & 1605 & 167 \\
\hline
\end{tabular}

- Statistically significant lower value (adjusted standardized residuals analysis)

+ Statistically significant higher value (adjusted standardized residuals analysis).

\section{Hypothesis 4}

Hypothesis 4 assumes there are statistically significant differences between nationals-natives and immigrants-foreigners in the variables of violent behavior, victimization, health problems, conversational richness, and personality traits. A multivariate analysis of variance (MANOVA) was performed to test this hypothesis, with the independent variable being the nationality of the character (national-native $v s$. immigrant-foreigner). The indices created concerning violent behavior, victimization, health problems, conversational richness, and the two personality trait factors (positive and negative features) were used as dependent variables. 
The MANOVA showed there were significant differences at a multivariate level (Wilks's Lambda $=.97, F_{\text {multivariate }}[6,1374]=5.10, p<.001, \eta_{\mathrm{p}}{ }^{2}$ $=.022$ ). When the differences between nationals-natives and immigrantsforeigners were analyzed at the univariate level, statistically significant differences were noted regarding the index of violent behavior $(F[1,1379]$ $\left.=17.91, p<.001, \eta_{\mathrm{p}}^{2}=.013\right)$ and in the victimization index $(F[1,1379]=$ $\left.5.58, p<.018, \eta_{\mathrm{p}}{ }^{2}=.004\right)$, the one referring to health problems $(F[1,1379]$ $\left.=8.86, p<.003, \eta_{\mathrm{p}}{ }^{2}=.006\right)$, conversational richness $(F[1,1379]=3.63$, $\left.p<.057, \eta_{\mathrm{p}}{ }^{2}=.003\right)$, and in the indicator of negative personality traits $(F$ $\left.[1,1379]=19.90, p<.001, \eta_{\mathrm{p}}^{2}=.014\right)$. No univariate statistically significant differences appeared in the index of positive personality traits $(F[1$, $\left.1379]=2.31, p<.129, \eta_{\mathrm{p}}{ }^{2}=.002\right)$. In short, immigrant-foreign characters scored higher than national-native ones in the indices of violent behavior, victimization, health problems and negative personality traits (see Table 6).

\section{Table 6}

\section{Differences Between National-Native Characters and Immigrants- Foreigners Regarding Violent Behavior, Victimization, Health Problems, Conversational Richness and Personality Traits (Multivariate Analysis of Variance, Manova)}

\begin{tabular}{|c|c|c|c|c|c|c|}
\hline \multirow[b]{2}{*}{ Variables (indices) } & \multicolumn{6}{|c|}{ Nationality } \\
\hline & National-Native & $\begin{array}{l}\text { Immigrant- } \\
\text { Foreigner }\end{array}$ & $\mathrm{F}$ & df & $\mathrm{p}$ & $\eta p 2$ \\
\hline Violence & 0.69 & 1.12 & 17.91 & 1,1379 & .000 & .013 \\
\hline [theoretical range: $0-5$ ] & $(1.14)$ & $(1.25)$ & & & & \\
\hline Victimization & 0.60 & 0.82 & 5.58 & 1,1379 & .018 & .004 \\
\hline [theoretical range: $0-5$ ] & $(1.02)$ & $(1.04)$ & & & & \\
\hline Health problems & 0.18 & 0.30 & 8.86 & 1,1379 & .003 & .006 \\
\hline [theoretical range: $0-5$ ] & $(0.44)$ & $(0.53)$ & & & & \\
\hline Conversational richness & 3.26 & 3.64 & 3.63 & 1,1379 & .057 & .003 \\
\hline [theoretical range: $0-15$ ] & $(2.26)$ & $(2.34)$ & & & & \\
\hline Positive personality traits & 2.04 & 1.97 & 2.31 & 1,1379 & .129 & .002 \\
\hline [theoretical range: $1-3$ ] & $(0.54)$ & $(0.52)$ & & & & \\
\hline Negative personality traits & 1.21 & 1.38 & 19.90 & 1,1379 & .000 & .014 \\
\hline [theoretical range: $1-3]$ & $(0.41)$ & $(0.53)$ & & & & \\
\hline $\mathrm{N}$ & 1239 & 142 & & & & \\
\hline
\end{tabular}

Note. the mean and the standard deviation (in parenthesis) are shown for each variable. 
As for health problems, the only variable for which there were statistically significant differences was alcohol consumption $\left(\chi^{2}[1, N=1772]=\right.$ $18.62, p<.001)$. It was much more frequent among immigrant-foreign characters $(19.8 \%)$ than among nationals-natives $(9.2 \%)$. With regard to specific differences in conversational topics associated with nationality, it was observed that immigrant-foreigners, compared to national-native characters, talked more frequently about work $\left(79.6 \%\right.$ versus $62.5 \% ; \chi^{2}[1, N=1772]$ $=19.32, p<.001)$, money $\left(37.7 \%\right.$ versus $29.6 \% ; \chi^{2}[1, N=1772]=4.72$, $p<.033)$, politics $\left(15.6 \%\right.$ versus $\left.9.4 \% ; \chi^{2}[1, N=1772]=6.38, p<.012\right)$, social difference $\left(10.8 \%\right.$ versus $\left.6 \% ; \chi^{2}[1, N=1772]=5.78, p<.016\right)$, immigration (9\% versus $2.8 \% ; \chi^{2}[1, N=1772]=17.65, p<.001$ ), and sports $\left(9.6 \%\right.$ versus $\left.5.7 \% ; \chi^{2}[1, N=1772]=3.91, p<.048\right)$. Conversely, although they exhibited more health problems than the national-native characters, immigrant-foreigners talked less than they did about health ( $23.4 \%$ versus $\left.29.4 \% ; \chi^{2}[1, N=1772]=3.17, p<.077\right)$. On the subject of specific differences in personality, immigrant-foreign characters scored higher than nationals-natives with respect to the following traits: aggressiveness $(t(158.63)$ $=-3.29, p<.001)$, conflictive $(t(152.75)=-3.99, p<.000)$, and disloyal or treacherous $(t(156.89)=-1.85, p<.066)$. At the same time, national-native characters were more "friendly" $(t(1433)=1.79, p<.072)$ and "kind or good-hearted" $(t(1353)=2.04, p<.016)$ than immigrants-foreigners. As a whole, the results obtained confirm Hypothesis 4.

\section{Conclusions}

The results of this content analysis study shed light on the biased or stereotypical construction of immigrant-foreigner characters in television fiction broadcast during prime time by the main national channels in Spain. Moreover, the established hypotheses are strongly supported by the data. Under-representation of immigrant-foreign characters is observed in fictional programs broadcast on prime-time Spanish television, since only 9.3\% of the characters portrayed in these programs are immigrants-foreigners, in contrast to the real life situation where $12.2 \%$ of the Spanish population is comprised of immigrants-foreigners Spain (INE, 2011). This under-representation is even greater in programs produced in Spain, where only $4.4 \%$ of the characters are immigrants-foreigners. This is almost eight percenta- 
ge points less than the actual presence of immigrants in Spain. In addition to this low presence or lack of diversity, the demographic and psychosocial variables showed clear differences between the representation of immigrant-foreign characters and national-native ones, depending on the role they played in the shows.

It was observed that immigrant-foreign characters were more likely to be case in antagonist or villain roles compared to national-native characters. Moreover, the educational level of immigrant-foreign characters, as opposed to national-native ones, is a feature less emphasized or stressed when building the personality of the fictional character. Furthermore, immigrants-foreigners, as opposed to nationals-natives, are depicted with a lower level of education, a lower socio-economic status, occupations that do not require specific skills, or appear performing criminal activities, behaving more violently and suffering more acts of violence (meaning their actions take place in more conflictive environments); they also exhibit more health problems (particularly associated with alcohol consumption), participate in conversations involving instrumental topics (work, money, social differences, politics, and immigration), and are defined with more negative personality traits (they are more aggressive, conflictive and disloyal or treacherous than national-native characters). The results obtained are convergent with previous studies done in the United States of America regarding ethnic minorities in television fiction (Mastro \& Greenberg, 2000; Mastro \& Behm-Morawitz, 2005). They also are in line with the study carried out by Igartua et al. (2012), based on a sample of 1,345 characters in fictional programs broadcast on Spanish prime-time television in 2010.

These results are important because the low presence of immigrantforeign characters (especially in Spanish productions); that is, the lack of diversity in television fiction, can condition their visibility or social vitality and, consequently, their status or perceived social strength; furthermore, it hinders the establishment of vicarious or parasocial contact between the native population and individuals of other national origins who have a notable presence in Spanish society (Harwood \& Anderson, 2002; Ortiz \& Harwood, 2007). Furthermore, the stereotypical and negative image of im- 
migrants-foreigners in the programs analyzed may lead to a reinforcement or assimilation of prejudicial attitudes towards immigrants. This is an aspect that should be tested in further studies.

Still, even though the media often have been part of the problem regarding the origin and maintenance of prejudice, they also could become part of the solution by contributing to a change in attitudes and individual and collective beliefs, by stimulating reflection and modeling innovative social norms. As mentioned, empirical evidence exists to the effect that vicarious contact provided through audiovisual consumption may favor the establishment of more harmonious relationships among citizens of different national and ethnic origin (Müller, 2009; Park, 2012). The practical implications deduced from this approach are evident: giving "publicity" (e.g. through fictional narratives such as a film or a television series) to positive interaction between members of the in-group (in our case, natives or nationals) and members of a stigmatized out-group (such as immigrants-foreigners) would help to reduce the perception of intergroup threat and improve attitudes towards migration. Such narratives could show how immigrants and natives interact positively, develop close relationships (as friends or couples), or resolve interpersonal conflicts emanating precisely from prejudice or stereotypes. Hence, a change in this tradition of building such negative characters and relationships should be stimulated in the production of fictional series, as has been undertaken in the field of journalism regarding coverage of immigration in the news. In addition, it is important to raise awareness among those who are responsible for syllabuses and plans at the undergraduate and graduate levels in communication studies as to the need for including education on diversity, mediated intergroup contact and prejudice.

\section{Acknowledgements}

We wish to thank the anonymous reviewers for their thoughtful suggestions during the revision process.

\section{Notes}

${ }^{1}$ We are well aware that two types of error can occur when coding a character's nationality in this sort of content analysis: false positives, when 
a character is considered an immigrant, but is not; and false negatives, when a character is considered a national or native, but is actually an immigrant or foreigner. Therefore, the following precautions were taken prior to coding. First, the analyst-coders were trained for three weeks, during which time they had an opportunity to work with the codebook and to analyze both Spanish and foreign programs. Secondly, the decision about a character's nationality was based fundamentally on the character's place of birth and the place where the action of the narrative was set (e.g. if the plot took place in Spain and the character was Spanish, the character was coded as a national; if the action was set in Mexico and the character was Mexican, the character was also coded as a "national of that country". In contrast, if the action was set in the United States and the character was defined as Spanish, the character was not classified as a national, but as an immigrant). When the evidence was not so clear, other criteria (visual, cultural, etc.) were used, but always taking into account the context of the program and the place where the action was set. In any case, we believe new studies (replications in other countries, outside the context of the United States) and perhaps new procedures are needed to determine the nationality of fictional characters more precisely. The origin of the program could affect the coding of this variable (as one reviewer of the manuscript suggested). Although, the number of appearances a character has in the program could be more influential in the coding of nationality than the country where the program was produced, since the level of information we have about characters who appear more sporadically is going to be less than the information on the characters who appear more often.

${ }^{2}$ Intercoder reliability also was calculated in the nationality variable for Spanish programs $(N=86)$ and foreign ones $(N=198)$. In both cases, it was shown to be satisfactory, although the reliability of this variable was slightly lower for the Spanish programs (Krippendorff's $\alpha=.66$ ) compared to the non-Spanish ones (Krippendorff's $\alpha=.80$ ). 


\section{References}

AIMC (2012). Resumen general Estudio General de Medios. Abril 2011 a mar$z o$ 2012. [Overall Summary - General Media Study. April 2011 to March 2012]. Madrid: Asociación para la Investigación de los Medios de Comunicación. Retrieved on May 20, 2012, from http:// www.aimc.es.

Allport, G. (1954). The nature of prejudice. Cambridge: Addison-Wesley.

Appel, M. (2008). Fictional narratives cultivate just-world beliefs. Journal of Communication, 58, 62-83.

Brader, T., Valentino, N. A., \& Suhay, E. (2008). What triggers public opposition to immigration? Anxiety, group cues, and immigration threat. American Journal of Political Science, 52(4), 959-978.

Cea D’Ancona, M. A. (2004). La activación de la xenofobia en España [The activation of xenophobia in Spain]. Madrid: CIS-Siglo XXI.

Cea D’Ancona, M. A., \& Valles, M. S. (2011). Evolución del racismo y la xenofobia en España [Evolution of racism and xenophobia in Spain]. Madrid: Ministerio de Trabajo y Asuntos Sociales, Observatorio Español del Racismo y la Xenofobia (OBERAXE).

Crisp, R. J., \& Turner, R. N. (2009). Can imagined interactions produce positive perceptions? Reducing prejudice through simulated social contact. American Psychologist, 64(4), 231-240.

Entman, R., \& Rojecki, A. (2000). The black image in the white mind. Chicago, IL: University of Chicago Press.

Fujioka, Y. (1999). Television portrayals and African-American stereotypes: Examination of television effects when direct contact is lacking. Journalism and Mass Communication Quarterly,76(1): 52-75. 
Galán, E. (2006). La representación de los inmigrantes en la ficción televisiva en España. Propuesta para un análisis de contenido. El Comisario y Hospital Central [The presentation of immigrants in Spanish fiction television. A proposal for a content analysis: El Comisario and Hospital Central]. Revista Latina de Comunicación Social, 61. Retrieved on January 20, 2011, from http://www.ull.es/publicaciones/latina/200608galan.htm

Gerbner, G., Gross, L., Morgan, M., Signorielli, N., \& Shanahan, J. (2002). Growing up with television: cultivation processess. In J. Bryant \& D. Zillmann (Comps.), Media effects. Advances in theory and research (pp. 43-68) Mahwah, NJ: Lawrence Erlbaum Associates.

Greenberg, B. S., \& Collette, C. (1997). The changing faces of TV. A demographic analysis of network television's new seasons, 1966-1992. Journal of Broadcasting and Electronic Media, 41(1), 1-13.

Greenberg, B. S., Mastro, J. E., \& Brand, J. E. (2002). Minorities and the mass media. Television into the 21 st century. In J. Bryant \& D. Zillmann (Eds.), Media effects. Advances in theory and research (pp. 201242). Mahwah, NJ: Lawrence Erlbaum Associates.

Harwood, J. (2010). The contact space: A novel framework for intergroup contact research. Journal of Language and Social Psychology, 29(2) 147-177.

Harwood, J., \& Anderson, K. (2002). The presence and portrayal of social groups on prime-time television. Communication Reports, 15 (2), 81-97.

Hayes, A. F., \& Krippendorff, K. (2007). Answering the call for a standard reliability measure for coding data. Communication Methods and Measures, 1(1), 77-89.

Igartua, J.J. (2010). Identification with characters and narrative persuasion through fictional feature films. Communications. The European Journal of Communication Research, 35(4), 347-373. 
Igartua, J.J., Barrios, I., \& Ortega, F. (2012). Analysis of immigration image in prime-time television fiction. Comunicación y Sociedad, 25(2), 5-28.

Igartua, J. J., \& Cheng, L. (2009). Moderating the effect of group cue while processing news on immigration. Is framing effect a heuristic process? Journal of Communication, 59(4), 726-749.

Igartua,J.J., Moral, F., \&Fernández, I. (2011). Cognitive, attitudinal and emotional effects of the news frame and group cues on processing news about immigration. Journal of Media Psychology, 23(4), 174-185.

Igartua, J.J., Muñiz, C., Otero, J. A. \& de la Fuente, M. (2007). El tratamiento informativo de la inmigración en los medios de comunicación españoles. Un análisis de contenido desde la Teoría del Framing [Informative treatment of immigration in the Spanish mass media. A content analysis based on the framing theory]. Estudios sobre el Mensaje Periodístico, 13, 91-110.

INE (2011). Avance del padrón municipal a 1 de enero de 2011. Datos provisionales. Nota de prensa [Preliminary population register report on January 1, 2011. Provisional data. Press release]. Madrid: Instituto Nacional de Estadística. Retrieved on May, 202012 fromhttp:// www.ine.es.

INE (2013). Avance de la estadística del padrón continúo a 1 de enero de 2013. Datos provisionales. Nota de prensa [Preliminary population register report on January 1, 2013. Provisional data. Press release]. Madrid: Instituto Nacional de Estadística. Retrieved on December 13, 2013 from http://www.ine.es.

Koeman, J., Peeters, A., \& D’Haenes, L. (2007). Diversity Monitor 2005. Diversity as a quality aspect of television in the Netherlands. Communications, 32, 97-121.

Lacalle, C. (2008). El discurso televisivo sobre la inmigración. Ficción y construcción de identidad [The television discourse on immigration. Fiction and identity construction]. Barcelona: Ediciones Omega. 
Mastro, D. (2009a). Effects of racial and ethnic stereotyping. In J. Bryant \& M. B. Oliver (Eds.), Media effects. Advances in theory and research (pp. 325-341). Nueva York, NY: Routledge ( $3^{\text {rd }}$ ed.).

Mastro, D. (2009b). Racial/ethnic stereotyping and the media. In R. L. Nabi \& M. B. Oliver (Eds.), Media processes and effects (pp. $377-$ 391). Thousand Oaks, CA: Sage.

Mastro, D.,\& Behm-Morawitz, E. (2005). Latino representation on primetime television. Journalism and Mass Communication Quarterly, 82(1), 110-130.

Mastro, D., \& Greenberg, B. S. (2000).The portrayal of racial minorities on prime time television. Journal of Broadcasting and Electronic Media, 44(4), 690-703.

Mastro, D., \& Robinson, A. L. (2000).Cops and crooks. Images of minorities on primetime television. Journal of Criminal Justice, 28, 385-396.

Molero, F. (2007). El estudio del prejuicio en la psicología social: definición y causas [The study of prejudice in social psychology: Definition and causes]. In J. F. Morales, M. C. Moya, E. Gaviria \& I. Cuadrado (Coords.), Psicología social (pp. 591-617). Madrid: McGraw-Hill (3a edition).

Morgan, M. (2009).Cultivation analysis and media effects. In R. L. Nabi \& M. B. Oliver (Eds.), Media processes and effects (pp. 69-82). Thousand Oaks, CA: Sage.

Morgan, M., \& Shanahan, S. (2010).The state of cultivation. Journal of Broadcasting and Electronic Media, 54(2), 337-355.

Morgan, M., Shanahan, S., \& Signorielli, N. (2009). Growing up with television: Cultivation processes. In J. Bryant \& M. B. Oliver (Eds.), Media effects. Advances in theory and research (pp. 34-49). Nueva York, NY: Routledge ( $3^{\text {rd }}$ ed. $)$. 
Müller, F. (2009).Entertainment anti-racism. Multicultural television drama, identification and perceptions of ethnic threat. Communications. European Journal of Communication Research, 34(3), 239-256.

Ortiz, M.,\& Harwood, J. (2007). A social cognitive theory approach to the effects of mediated intergroup contact on intergroup attitudes. Journal of Broadcasting and Electronic Media, 51(4), 615-631.

Paluck, E. L. (2009). Reducing intergroup prejudice and conflict using the media: A field experiment in Rwanda. Journal of Personality and Social Psychology, 96(3), 574-589.

Park, S. Y. (2012). Mediated intergroup contact: Concept explication, synthesis, and application. Mass Communication and Society, 15(1), 136-159.

Pettigrew, T. F., \& Tropp, L. R. (2006). A meta-analytic test of intergroup contact theory. Journal of Personality and Social Psychology, 90(5), 751-783.

Pettigrew, T. F., \&Tropp, L. R. (2008). How does intergroup contact reduce prejudice? Meta-analytic tests of three mediators. European Journal of Social Psychology, 38, 922-934.

Potter, W. J., \& Warren, R. (1998). Humor as camouflage of televised violence. Journal of Communication, 48(2), 40-57.

Ruiz-Collantes, X., Ferrés, J., Obradors, M., Pujadas, E., \& Pérez, O. (2006). La imagen pública de la inmigración en las series de televisión españolas [The public image of immigration in Spanish television series]. Política y Cultura, 26, 93-108.

Schemer, C. (2012).The influence of news media on stereotypic attitudes toward immigrants in a political campaign. Journal of Communication, 62, 739-757. 
Schiappa, E., Gregg, P. B., \& Hewes, D. E. (2005). The parasocial contact hypothesis. Communication Monographs, 72, 92-115.

Shanahan, J.,\& Morgan, M. (1999). Television and its viewers. Cultivation theory and research. Cambridge: Cambridge University Press.

Shrum, L. J., Lee, J., Burroughs, J. E., \& Rindfleisch, A. (2011). An online process model of second-order cultivation effects: How television cultivates materialism and its consequences for life satisfaction. Human Communication Research, 37, 34-57.

Signorielli, N., \& Morgan, M. (1996). Cultivation analysis: Research and practice. In M. B. Salwen \& D. W. Stacks (Eds.), An integrated approach to communication theory and research (pp. 111-126). Mahwah, NJ: Lawrence Erlbaum Associates.

Wright, S. C., Aron, A., McLaughlin-Volpe, T.,\& Ropp, S. A. (1997). The extended contact effect: Knowledge of cross-group friendships and prejudice. Journal of Personality and Social Psychology, 73(1), 73-90. 